\title{
Negative plant-soil feedback and positive species interaction in a herbaceous plant community
}

\author{
Giuliano Bonanomi ${ }^{1}$, Max Rietkerk ${ }^{2}$, Stefan C. Dekker ${ }^{2}$ and Stefano Mazzoleni ${ }^{1, *}$ \\ ${ }^{1}$ Dipartimento di Arboricoltura Botanica e Patologia Vegetale, Università degli Studi di Napoli Federico II, \\ Italy; ${ }^{2}$ Department of Environmental Sciences, Utrecht University, PO Box 80115, 3508 TC Utrecht, The \\ Netherlands; *Author for correspondence (e-mail: stefano.mazzoleni@unina.it; fax: +39-81-7760104)
}

Received 16 February 2005; accepted in revised form 11 May 2005

Key words: Central die-back, Facilitation, Lithium, Phalanx type, Scirpus holoschoenus, Soil bioassay, Soil seed-bank

\begin{abstract}
Increasing evidence shows that facilitative interaction and negative plant-soil feedback are driving factors of plant population dynamics and community processes. We studied the intensity and the relative impact of negative feedback on clonal growth and seed germination of Scirpus holoschoenus, a 'ring' forming sedge dominant in grazed grassland, and the consequences for species coexistence. The structure of aboveground tussocks was described. A Lithium tracer assessed belowground distribution of functional roots. Seed rain and seedling emergence were compared for different positions in relation to Scirpus tussocks. Soil bioassays were used to compare growth on soil taken from inside and outside Scirpus tussocks of four coexisting species (Mentha acquatica, Pulicaria dysenterica, Scirpus holoschoenus and Dittrichia viscosa). We also compared plant performance of dominant plant species inside and outside Scirpus tussocks in the field. The 'ring' shaped tussocks of $S$. holoschoenus were generated by centrifugal rhizome development. Roots were functional and abundant under the tillers and extending outside the tussocks. The large roots mats that were present in the inner tussock zone were almost all dead. Seedling emergence and growth both showed a strong negative feedback of Scirpus in the inner tussock zone. Scirpus clonal development strongly reduced grass biomass. In the degenerated tussock zone, Pulicaria and Mentha mortality was lower, and biomass of individual plants and seed production were higher. This positive indirect interaction could be related to species-specific affinity to soil conditions generated by Scirpus, and interspecific competitive release in the degenerated tussock zone. We conclude that Scirpus negative feedback affects its seedling emergence and growth contributing to the development of the degenerated inner tussock zone. Moreover, this enhances species coexistence through facilitative interaction because the colonization of the inner tussock zone is highly species-specific.
\end{abstract}

\section{Introduction}

Clonal herbaceous plants often become dominant affecting the structure and functioning of plant communities (Grime 1998). The common 'phalanx' type growth strategy leads to densely aggregated clones with lower ramet density in the centre; a pattern referred to as fairy-ring or central die-back (Wikberg and Svensson 2003). The degeneration of the central area of the tussock has 
been interpreted as the results of the architectural development of the genet (Danin 1996), increase of interspecific competition inside the clones (Castellanos et al. 1994) or, alternatively, as a consequence of changes in abiotic factors or resource levels (Falinska 1995; Wikberg and Mucina 2002). Plant-soil 'negative feedback' is a specific case of such plant-induced soil heterogeneity Bever 1994). Such feedback is defined as the negative condition for the establishment, growth and reproduction of individuals under their parent plants. This has been reported in relation to succession (Van der Putten et al. 1993; Little and Maun 1996), coexistence (Streng et al. 1989; Bever 1994; Wills et al. 1997; Blomquist et al. 2000), and invasion processes (Klironomos 2002).

Mechanisms that have been proposed to explain this negative feedback include soil nutrient depletion, the build-up of soil-borne pathogen populations (De Rooij-van Der Goes 1995; Packer and Clay 2000), the changing community composition of soil microbial organisms (Bever 1994), and the release of allelopathic compounds during organic matter decomposition (Singh et al. 1999; Armstrong and Armstrong 2001). Species distribution can be affected by negative feedback depending on life form and propagation patterns. For instance, trees and shrubs can escape from 'home' soil (sensu Bever 1994) via seed dispersion (Augspurger and Kelly 1984; Packer and Clay 2000), whereas perennial clonal plants can move away by vegetative growth (Van der Putten 2003). Several studies showed how negative feedback affects the spatial distribution of clonal modules (Olff et al. 2000), thus indicating that the foraging of plant rhizomes depends on that local environmental heterogeneity (Hutchings and de Kroon 1994). Negative feedback involves effects on the same species, while effects on other species are strongly species-specific (Van der Putten et al. 1993; Bever 1994; Olff et al. 2000; Bonanomi and Mazzoleni 2005), suggesting an important role in the competitive relation between coexisting species (Bever et al. 1997; Bever 2003; Bonanomi et al. 2005).

Despite the large body of empirical evidence of negative plant-soil feedback, the hypothesis that this is associated with the central dieback of perennial plant tussocks has not been proposed so far. Moreover, co-occurring species could be affected by the conditions generated by the clones in their degenerated zone.
Interspecific facilitative interactions have been recently recognised as an important factor for plant community organization (Bertness and Hacker 1994; Callaway 1995; Callaway et al. 2002). Such interactions are common between ring-forming plants and others species that colonise the degenerated zone (Watt 1947; Curtis and Cottam 1950). However, empirical evidence of such interactions only exists for ring-forming plants in communities either with low productivity or affected by chronic environmental stress (Pedemasa 1981; Castellanos et al. 1994; Casal et al. 2001; Benjamin et al. 2004). 'Nurse' plants buffer harsh environmental conditions creating niches for other species, allowing species coexistence (Bruno et al. 2003).

Our study was aimed to understand how Scirpus holoschoenus central dieback affects the performance of co-occurring species, thus allowing their coexistence by facilitative interactions. Specifically, in this study we tested the hypotheses that (1) the dominant $S$. holoschoenus tussocks induce negative plant-soil feedback in the inner degenerated tussock zones, leading to lower seed regeneration; (2) other species respond to Scirpus plant-soil feedback in a species-specific way; and (3) competitive release results in indirect facilitative interaction within these zones in this highly productive grassland.

\section{Methods}

Study site

The study site is a grazed grassland on an alluvial soil along the Metauro River in Eastern Central Italy $\left(43^{\circ} 51^{\prime} 46^{\prime \prime}-13^{\circ} 00^{\prime} 22^{\prime \prime}\right)$. Vegetation structure is characterised by large Scirpus tussocks (average height $120 \mathrm{~cm}$ ) mainly surrounded by grasses. Dominant species are the sedge $S$. holoschoenus, the grasses Festuca arundinacea, Dactylis glomerata and Holcus lanatus and the forbs Dittrichia viscosa, Pulicaria dysenterica and Mentha acquatica (species are indicated hereafter solely with generic name). Mean annual rainfall is $754 \mathrm{~mm}$ with a moderate dry season during summer months causing dry conditions. Mean monthly temperatures are between $23.6^{\circ} \mathrm{C}$ (July) and $3.8^{\circ} \mathrm{C}$ (January) (averages of 50 years observation; Fano meteorological station, $5 \mathrm{~km}$ from study site). 
The experimental plot was $100 \times 20 \mathrm{~m}$ parallel to the river in an area, which is periodically flooded in winter and spring. No evidence of sediment accretion and water logging was present. The site is periodically grazed at low intensity by horse and sheep and is not mowed.

\section{Scirpus tussocks structure, seed dispersal and soil seed bank}

In total 21 large (diameter $>100 \mathrm{~cm}$ ) Scirpus tussocks were randomly selected, avoiding coalescent clumps. Aboveground structure was studied using a cross-section of each tussock. In each sampling point of $5 \times 5 \mathrm{~cm}$ at every $5 \mathrm{~cm}$ of the cross-sections, the flowering, vegetative, stunted and dead tillers were counted. Photosynthetic active radiation (PAR 400-700 nm; instrument ADC-L2A light sensor) was measured at 0, 20, 40, 60,80 and $100 \mathrm{~cm}$ height above the surface, at every $15 \mathrm{~cm}$ along the transects crossing the Scirpus tussock, and extending for another $45 \mathrm{~cm}$ on each side of the tussocks. Measurements were made under bright, sunny conditions around midday in July 2001.

Functional root systems of large Scirpus tussocks were assessed using Lithium as a nonradioactive tracer (Fitter 1986). At the end of the dry season $(29 / 09 / 2001)$, ten large tussocks were randomly selected and divided in two groups of five tussocks. Tracer solutions $(10 \mathrm{ml}$ of $\mathrm{LiCl}$ at $10,0 \mathrm{mg} \mathrm{ml}^{-1}$ ) were injected at 10 and $25 \mathrm{~cm}$ soil depth with an automatic pipette in soil holes made with a steel tube. Injections were made inside the first group of five Scirpus tussocks and $20 \mathrm{~cm}$ outside the first living tiller of the other group of 5 tussocks. After 31 days, 100 tillers that were most close to each injection point were removed from the tussocks. In total 1000 tillers were treated for $\mathrm{Li}$ extraction by warm water $\left(+90^{\circ} \mathrm{C}\right)$ for $12 \mathrm{~h}$ followed by filtering (Martin et al. 1982) to measure the Li filtrate content by ionic chromatography.

In order to compare seed rain and seedling emergence, the size of the germinable seed bank was assessed by soil collected at different distances from Scirpus tussocks. Seed dispersal was measured by the seed trap method (glass tubes, $13 \mathrm{~mm}$ diameter $\times 200 \mathrm{~mm}$ depth). One trap was placed inside the degenerated zone (IN) and 3 outside (OUT) 15 tussocks at 1,5 and $15 \mathrm{~m}$ from the nearest plant, resulting in a total of 60 traps. Seed traps were placed on the surface in July 2001 one month before the start of seed release. Seed rain was measured monthly for the following six months by counting the Scirpus seeds in the laboratory by a light microscope. In April 2001, Scirpus germinable soil seed bank was measured by sampling the top-soil (first $5 \mathrm{~cm}$ ) at three positions for each of the 15 tussocks; inside the tussock, and outside at 5 and $15 \mathrm{~m}$ from the nearest plant, resulting in a total of 45 samples. Aboveground litter was removed and the soil was thoroughly mixed and $150 \mathrm{~g}$ dry weight samples were placed on plastic trays under controlled conditions $\left(+28^{\circ} \mathrm{C}, 200 \mu \mathrm{mol} \mathrm{m}^{-2} \mathrm{~s}^{-1}, 16: 8\right.$ ratio day-night). The trays were watered daily to keep the soil moist while avoiding water logging. The numbers of germinated Scirpus seedlings were counted weekly during three months, and all emerged seedlings were removed to minimise possible density-dependent effects on further germination.

\section{Soil bioassay}

Soil bioassay experiments were conducted for two soil types, one collected in the degenerated Scirpus zone and the other from the surrounding grassland not affected by Scirpus. The effect of soil type on seedling growth of Scirpus and the three most frequent forbs Dittrichia, Pulicaria and Mentha were assessed. On February 2001, ten large Scirpus tussocks were randomly chosen and soil inside and $1 \mathrm{~m}$ outside each tussock was collected at $0-20 \mathrm{~cm}$ depth. Aboveground litter was removed, soil material was sieved $(<2 \mathrm{~mm})$ and the large roots, rhizomes and buried leaves were cut $(<2 \mathrm{~mm})$ and reintroduced into the soil (for details see Van der Putten et al. 1993). For every soil sample the following physical and chemical parameters were analysed: sand $\%$, loam $\%$ and clay $\%, \mathrm{EC}, \mathrm{pH}$, organic matter (\%), total $\mathrm{N}, \mathrm{P}_{2} \mathrm{O}_{5}, \mathrm{~K}_{2} \mathrm{O}, \mathrm{CaCO}_{3}$, $\mathrm{CaO}, \mathrm{MgO}$. Pots, $12 \mathrm{~cm}$ in diameter and $15 \mathrm{~cm}$ in height, were filled with $200 \mathrm{~g}$ of dry weight soil. Seeds were collected in the field from more then 50 individuals for each of the four species and placed on Petri dishes. One pre-germinated seedling was placed in each pot in a growth chamber $\left(+25^{\circ} \mathrm{C}\right.$, $220 \mu \mathrm{mol} \mathrm{m}^{-2} \mathrm{~s}^{-1}$ photons; 16:8 ratio day-night), according to a completely random design with 
regular rotation. Pots were wetted every two days with distilled water until water holding capacity was reached. Every species grew in both soil types with 10 replicates resulting in a total of 80 pots. After 55 growing days, shoots and roots were harvested, washed with tap water, and dry weight was measured (after $80^{\circ} \mathrm{C}$ for $72 \mathrm{~h}$ ).

\section{Photosynthesis and growth in the field}

Fieldwork was done during two years (2001 and 2002) to compare community and species performance inside and outside Scirpus tussocks. The following variables were measured:

i) Community biomass was measured in both years at the end of the growing season (December) by squared sample frames which were placed inside $(10 \times 10 \mathrm{~cm} ; n=5)$ and outside $(20 \times 20 \mathrm{~cm}$; $n=5) 10$ randomly sampled tussocks of Scirpus. The small frames were used inside the tussock because of limited space. Vegetation was cut at the ground level to measure biomass for every growth form (forbs, grasses, $\mathrm{N}$-fixer) and dry weight was measured in the laboratory $\left(+80^{\circ} \mathrm{C} 72 \mathrm{~h}\right)$.

ii) The density and mortality of adult Mentha and Pulicaria plants were measured at the end of the dry season (September). For ten randomly sampled tussocks, all alive and dead adult plants were counted in squared frames $(20 \times 20 \mathrm{~cm})$, which were placed outside $(n=4)$ and inside $(n=4)$ the tussocks (total of 80 sample squares). To estimate Pulicaria seed production, we measured capitula numbers and diameters of all plants $(n=946$ and $n=573$ in 2001 and 2002, respectively) rooted inside and within $2 \mathrm{~m}$ outside 10 randomly selected tussocks. Pulicaria individual seed production was estimated by a linear regression $\quad\left(R^{2}=0.87, \quad F=191, \quad p<0.001\right)$ between capitula diameters $(n=30)$ and number of seeds per capitulum (total measured seeds was 4124).

iii) Photosynthetic rates of Mentha and Pulicaria were measured four times during the growing season (June, July, August and September) in 2001. Measurements were done on randomly sampled plants rooted both inside and outside four large randomly selected Scirpus tussocks. For each plant, two leaves were measured (one sub apical and a median leaf). The number of plants sampled for each species for different days ranged between 22 and 30. Photosynthetic rates and air temperatures were measured by a portable infrared gas analyzer (ADC-L2A) around midday on cloudless days.

\section{Results}

The tussocks of Scirpus showed a consistent spatial pattern of vegetative, flowering, stunted and dead tillers (Figure 1). We found an absence of tillers in the inner zone, the prevalence of dead tillers in the inner tussock zone and higher tiller density with a dominance of flowering stems in the external tussock zone. This tiller distribution and density reflect centrifugal growth of individual rhizomes generating the typical 'ring' shape of the tussocks; a central area without tillers surrounded by a ring with high tiller density. Significant light attenuation occurred (Figure 2) in the peripheral tussock zone because of the higher tiller density as compared to the light levels of tussock centres and of surrounding areas dominated by grasses.

Lithium concentration of the leaves was two orders of magnitude higher in Scirpus plants where the tracer was injected outside the tussocks as compared to inside (Figure 3). Thus, a reduced root activity in the inner zone of the ring occurred, which could not be attributed to lower densities of roots within the rings (Picture 1).

The seed rain of Scirpus showed a sharp decrease with increasing distance from the centre of the tussocks (Figure 4a). The number of seeds deposited was two orders of magnitude higher inside the tussocks as compared to $1 \mathrm{~m}$ and $5 \mathrm{~m}$ outside the tussocks. No seeds were present in traps at $15 \mathrm{~m}$ from the tussock. Scirpus germinable soil seed bank was largest in soil sampled at $5 \mathrm{~m}$ outside from the tussock, while no difference was found between the soil inside and $15 \mathrm{~m}$ outside the nearest tussock (Figure 4b).

In the bioassay experiments, seedling growth was significantly affected in a species-specific way by soil taken from inside as compared to outside the tussocks (Figure 5). Mentha and Pulicaria did not show growth differences related to soil type but Dittrichia and Scirpus showed a growth reduction in soil collected from inside the tussocks. 

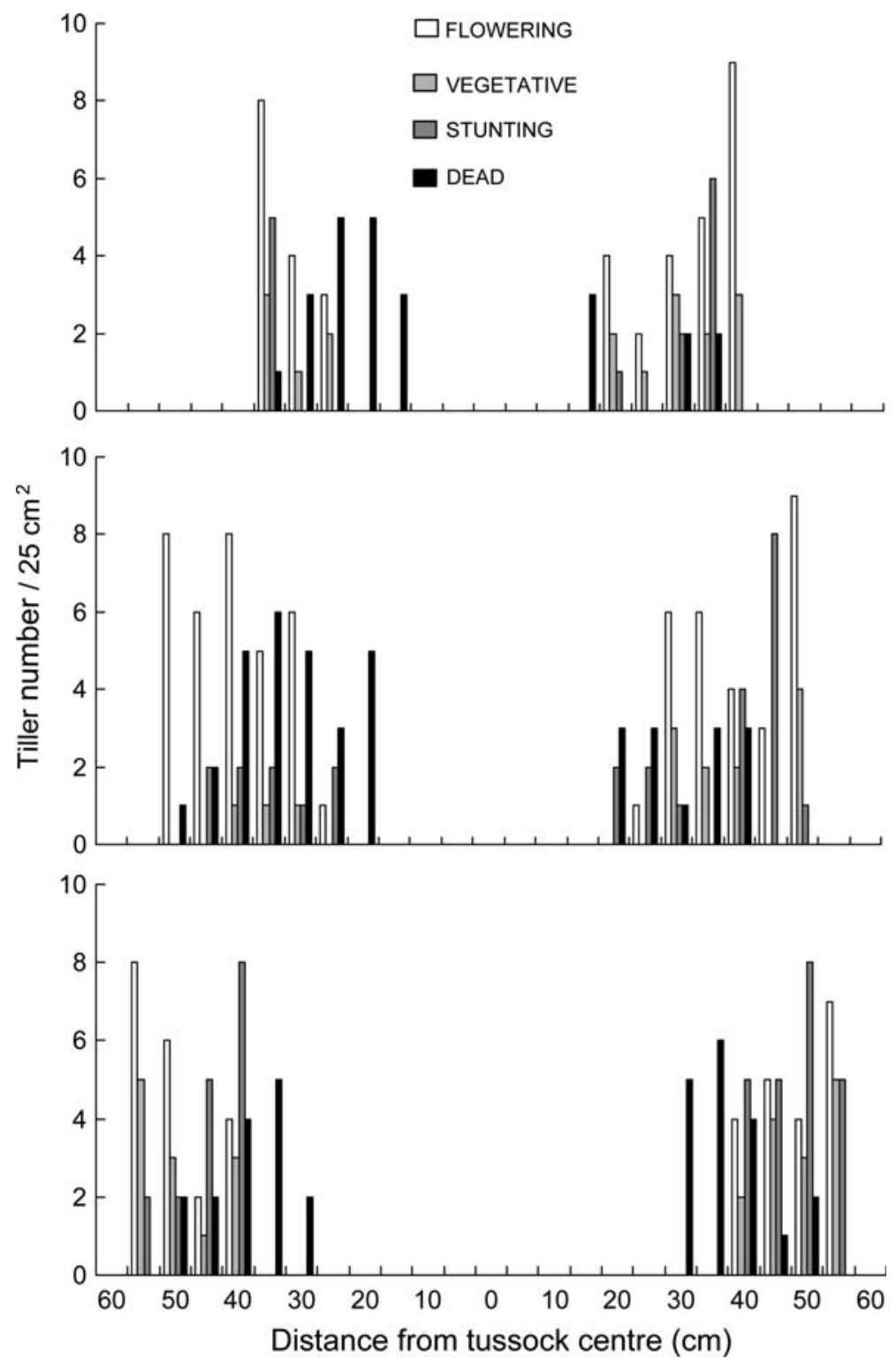

Figure 1. Characteristic structures of Scirpus holoschoenus tussocks showing three different clones sized between 70 and $110 \mathrm{~cm}$ diameter.

No differences of soil parameters between soil samples taken from inside the tussocks as compared to outside were found (Table 1).

Total biomass and grass biomass were higher outside than inside the tussocks in both years (Table 2). The sum of forb (excluding Pulicaria and Mentha) and $\mathrm{N}$-fixing species biomass was low, without differences related to the position of tussocks in the first year. In the second year, this sum was slightly higher outside the Scirpus tussocks (Table 2).
Photosynthetic rates of Mentha were higher on plants rooted inside the Scirpus tussocks in June and September, while in July and August the values were close to zero because of drought conditions (Figure 6a). Photosynthetic rates of Pulicaria were also higher in plants rooted inside Scirpus tussocks in June, August and September (Figure 6b).

The mortality of Mentha and adult Mentha density were higher outside than inside Scirpus tussocks in the first year (Table 2). Biomass per 


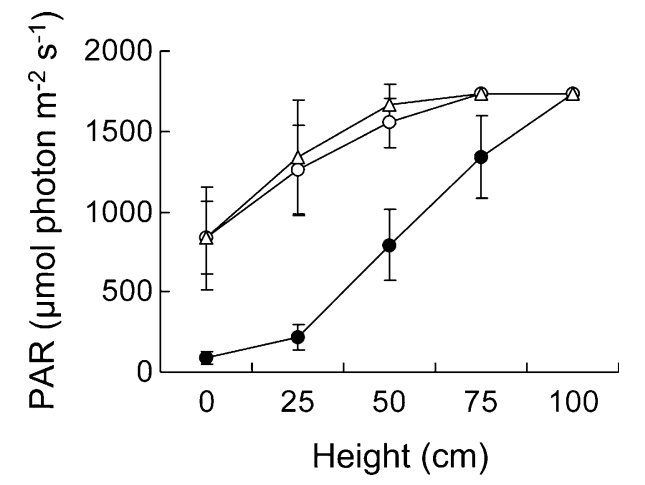

Figure 2. Light intensity at different heights above the substrate according to position in relation to Scirpus holoshoenus tussocks: outside tussock (triangle), within the tiller belt (filled circle) and inside the degenerated zone (open circle). Bars indicate standard error.

individual Mentha plant was higher inside than outside the tussocks in both years. A higher Pulicaria mortality and adult plant density were observed outside than inside the tussocks in the first year (Table 2). Pulicaria seed production was higher for plants rooted inside than outside Scirpus tussocks. In the first year, only $23 \%$ of Pulicaria individuals rooted outside Scirpus tussocks produced seeds, while this was true for $71 \%$ of the individual plants rooted inside the tussocks. In the second year, the same trend was found in seed production with an overall increased plant performance: $56 \%$ and $86 \%$ of Pulicaria plants produced seeds when rooted outside and inside the tussock, respectively. Regression analysis on the first-year data showed that Mentha and Pulicaria plant biomass $\left(\mathrm{g} \mathrm{m}^{-2}\right)$ was negatively correlated with grass biomass $\left(\mathrm{g} \mathrm{m}^{-2}\right)$ (respectively $n=57$, $R^{2}=0.36 p<0.001$ and $n=44, R^{2}=0.34$, $p<0.001)$.

\section{Discussion}

Accumulating evidence indicates that positive plant interactions are common (Callaway 1995; Bruno et al. 2003). Indeed, facilitation has been considered as an important factor for structuring plant communities of harsh environments (Callaway and Walker 1997; Callaway et al. 2002; Bruno et al. 2003). Our study demonstrates positive interactions in a relative productive environment, where plant communities are not subject to chronic abiotic stress. This paper reports on positive species interactions most likely arising from negative plant-soil feedback of Scirpus. Scirpus has centrifugal tillers (Figure 1), rhizomes and root growth (Figure 3), generating tussocks that are regular 'ring' shaped. This centrifugal rhizome growth produces a clear above and belowground competitive release in the degenerated zones. This allows specific species to colonise these zones. Scirpus germinable soil seed bank is reduced in these zones (Figure 4), which are associated with negative plant-soil feedback (Figure 5), and where seed regeneration is even absent in the field (personal observation, Figure 1). Grass biomass is reduced inside the tussocks, and Pulicaria and Mentha performed better inside these tussocks (Table 2). The different Mentha and Pulicaria mortality and Pulicaria seed production between years (Table 2) could be related to summer drought in the first year. Precipitation was $26.2 \mathrm{~mm}$ in July and August 2001, compared to $213.6 \mathrm{~mm}$ during the same period of 2002. Plant mortality of Pulicaria and Mentha was due to dry conditions, while dead plants were standing without any signs of external damage (personal observations), thus showing no effect of grazing.
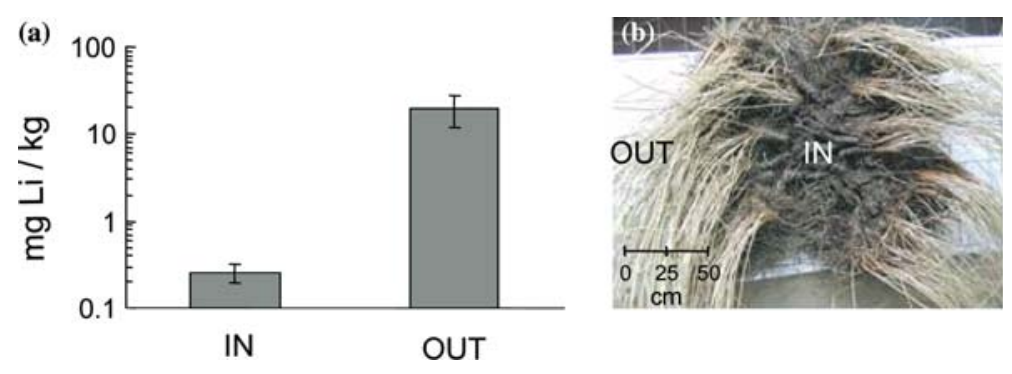

Figure 3. (a) Lithium content ( $\mathrm{mg} \mathrm{Li} \mathrm{kg}{ }^{-1}$ dry weight biomass) of tillers 31 days after soil injection of a tracer solution inside (IN) and outside (OUT) Scirpus holoshoenus tussocks. Results show a significant (paired $t$-test $p<0.01$ ) difference of root absorption activity. (b) Excavated Scirpus tussock (diameter $140 \mathrm{~cm}$ ) with dense mats of dead rhizomes and roots in the inner degenerated zone (IN). 

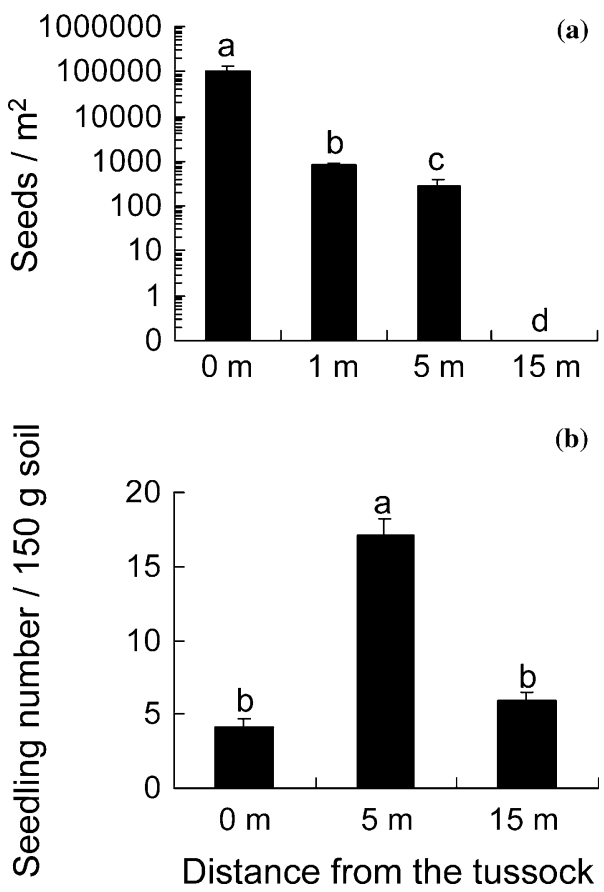

Figure 4. Contrasting patterns of (a) seed rain and (b) seedling emergence for Scirpus holoschoenus in relation to distance from nearest tussock. Distance of $0 \mathrm{~m}$ is inside the rings in the dieback zone, distances $>0$ are outside the rings, measured as distance from nearest tussocks. Different letters indicate significant differences (One-way ANOVA).

The plant-soil feedback generated by Scirpus plants strongly affects growth in a species-specific way (Figure 5). Soil differences were not apparent from common soil analysis (Table 1). Our results show that this species-specific affinity between plants and soil present inside and outside the Scirpus is likely to play a role in the colonization of the degenerated tussock zone. This is also suggested by the fact that Pulicaria and Mentha did not show growth reduction on soil from within the 'rings' (Figure 5). These species showed higher performance (survival, growth and seed production) in the degenerated tussock zones than outside the Scirpus tussocks in the field. Such indirect positive interaction of Scirpus with Pulicaria and Mentha is probably not only due to their affinity for soil within the 'rings' (Figure 5), but could also be due to above and belowground competitive release by Scirpus and grasses in the degenerated zone (Table 2). To our knowledge, this is the first evidence of interspecific facilitation in a productive environment arising from competitive release of dominant species.

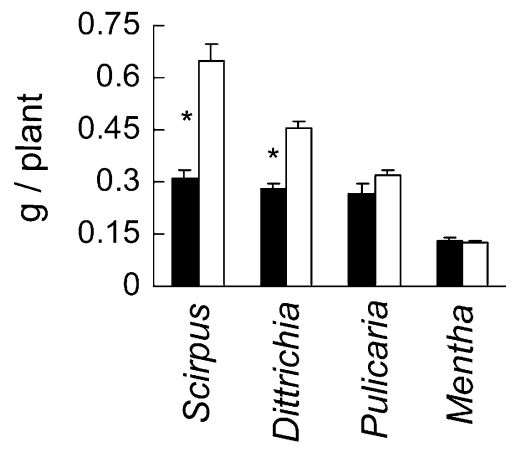

Figure 5. Seedling dry biomass ( $\mathrm{g}^{-1}$ plant) of 4 different species under controlled conditions on soil collected inside (filled bars) and outside (open bars) Scirpus holoschoenus tussocks. Asterisks indicate significant differences $(t$-test $p<0.05)$, bars indicate SE $(n=10)$.

In this study, soil analysis excluded that negative plant-soil feedback could be attributed to differences in the soil nutrient pools (Table 1). This is in agreement with previous findings by Zucconi (1994). Still, comparisons between seed rain and seedling emergence of Scirpus at different locations (Figure 4) indicate that seed germination is strongly inhibited in the inner tussock area. Additionally, Scirpus seedling growth showed a strong negative plant-soil feedback in the 'rings' (Figure 5). This evidence of negative plant-soil feedback, coupled with the recorded prevalence of Scirpus active root systems outside the tussock, suggests that roots may escape from inhospitable soil of the degenerated zone. Therefore, we hypothesise that this may drive the

Table 1. Soil parameters sampled inside (IN) and outside (OUT) Scirpus holoschoenus tussocks.

\begin{tabular}{llll}
\hline Soil parameter & IN & OUT & $t$-test \\
\hline Sand $(\%)$ & 37 & 30.5 & $p=0.054$ \\
Loam $(\%)$ & 24.5 & 33.5 & $p=0.12$ \\
Clay $(\%)$ & 38.5 & 36 & $p=0.32$ \\
$\left.\mathrm{EC}(\mathrm{mS} \mathrm{cm})^{-1}\right)$ & 0.2 & 0.22 & $p=0.27$ \\
$\mathrm{pH}$ & 7.41 & 7.46 & $p=0.35$ \\
Organic matter $(\%)$ & 2.49 & 2.35 & $p=0.11$ \\
$\mathrm{~N}$ total $(\%)$ & 0.28 & 0.28 & $p=0.50$ \\
$\mathrm{P}_{2} \mathrm{O}_{5}\left(\mathrm{mg} \mathrm{kg}^{-1}\right)$ & 9.23 & 9.17 & $p=0.48$ \\
$\mathrm{~K}_{2} \mathrm{O}\left(\mathrm{mg} \mathrm{kg}^{-1}\right)$ & 479.9 & 496.5 & $p=0.37$ \\
$\mathrm{CaO}\left(\mathrm{mg} \mathrm{kg}^{-1}\right)$ & 2811.5 & 2716.5 & $p=0.35$ \\
$\mathrm{MgO}\left(\mathrm{mg} \mathrm{kg}^{-1}\right)$ & 145 & 139 & $p=0.39$ \\
\hline
\end{tabular}

Data are means ( $n=5$ for all parameters), all comparisons were performed with paired $t$-test. 
Table 2. Biomass and performance of species rooted inside (IN) and outside (OUT) Scirpus holoschoenus tussocks.

\begin{tabular}{|c|c|c|c|c|c|c|c|}
\hline \multirow[t]{2}{*}{ Species } & \multirow[t]{2}{*}{ Parameter } & \multicolumn{3}{|c|}{ Year 2001} & \multicolumn{3}{|c|}{ Year 2002} \\
\hline & & IN & OUT & $t$-test & IN & OUT & $t$-test \\
\hline \multirow[t]{3}{*}{ Mentha acquatica } & Density (plants $\mathrm{m}^{-2}$ ) & 22.1 & 91.2 & $p<0.01$ & 7.9 & 17.1 & $p=0.06$ \\
\hline & Adult mortality (\%) & 38.1 & 98.8 & $p<0.01$ & 0 & 0 & $p=1$ \\
\hline & Biomass (g/plant) & 1.24 & 0.42 & $p<0.01$ & 1.10 & 0.51 & $p<0.01$ \\
\hline \multirow[t]{3}{*}{ Pulicaria dysenterica } & Density (plants $\mathrm{m}^{-2}$ ) & 30.2 & 53.1 & $p<0.01$ & 23.9 & 18.7 & $p=0.23$ \\
\hline & Adult mortality (\%) & 7.7 & 28 & $p=0.08$ & 6 & 15.8 & $p<0.01$ \\
\hline & Seed production (seeds/plant) & 1138 & 93 & $p<0.01$ & 1690 & 460 & $p<0.01$ \\
\hline Other forbs $+\mathrm{N}$-fixer & Biomass $\left(\mathrm{g} \mathrm{m}^{-2}\right)$ & 4.2 & 10.9 & $p=0.08$ & 0 & 17 & $p<0.01$ \\
\hline Grasses & Biomass $\left(\mathrm{g} \mathrm{m}^{-2}\right)$ & 109.9 & 645.3 & $p<0.01$ & 119.1 & 485.1 & $p<0.01$ \\
\hline Grasses + forbs $+\mathrm{N}$-fixer & Biomass $\left(\mathrm{g} \mathrm{m}^{-2}\right)$ & 251.1 & 681.5 & $p<0.01$ & 173.7 & 529.4 & $p<0.01$ \\
\hline
\end{tabular}

Grass biomass is the sum of Holcus, Dactylis and Festuca. Density, mortality, biomass of individual plants (g/plant) and seed production were measured at the end of the dry season (September), while biomass per unit surface area $\left(\mathrm{g} \mathrm{m}^{-2}\right)$ was measured at the end of the growing season (December). Data are means (see Methods section for sample size of each parameter), all comparisons were performed by paired $t$-test.

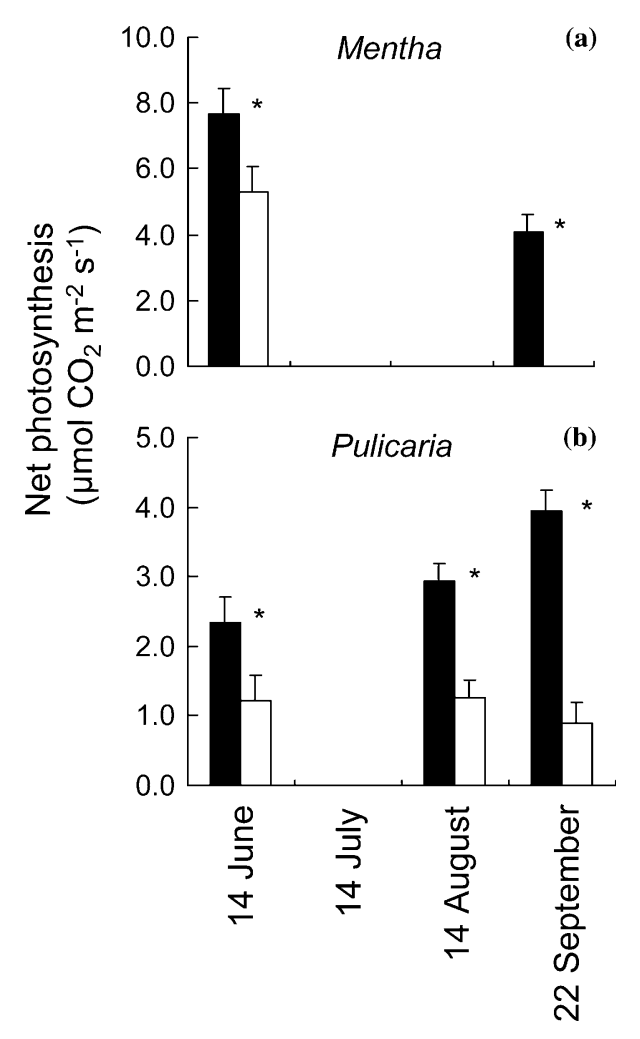

Figure 6. Photosynthesis of (a) Mentha and (b) Pulicaria according to their position in relation to Scirpus holoschoenus tussocks (open and filled bars referring to OUT and IN location, respectively). Asterisks refer to significant differences (paired $t$-test $p<0.01$ ). On 22 September, all Mentha individuals located outside the tussocks were dead.

centrifugal rhizome vegetative growth. Other experimental studies in root observation chambers (Bonanomi 2002) showed that root growth of Scirpus seedlings was reduced on soil from within the 'rings'.

This study allows us to reject some alternative possibilities explaining centrifugal rhizome development. Interspecific competition is probably not involved in the Scirpus ring growth because the total aboveground biomass (grass + forbs $+\mathrm{N}$ fixer) inside the tussock was always much lower than in the outer area, where Scirpus roots show preferential development (Table 2, Figure 3). Intraspecific competition between rhizomes of the same tussock can also be excluded to explain the absence of regeneration in the degenerated tussock area, because living above and belowground structures are almost absent in the centre of large tussocks (Figures 1-3). Moreover, competition hypotheses are in contrast with evidence from other studies, where both centrifugal development and inner clones dieback have been reported to occur irrespective whether other species were able or not to colonise the degenerated central 'ring' zone (Watt 1947; Bonanomi 2002).

Although our experimental evidence showed the occurrence of Scirpus negative plant-soil feedback, our data are not conclusive to demonstrate that negative feedback is involved in the initiation of 'ring' development. Nevertheless, we hypothesise that Scirpus negative plant-soil feedback is the primary necessary driver of centrifugal rhizome growth and the generation of 'ring' tussock development. Further studies are needed to test this hypothesis.

This study supports the view that negative plant-soil feedback at individual level is involved 
in plant coexistence at community scale (Bever et al. 1997; Bonanomi et al. 2005). At the community level the presence of different species is fundamental to maintain vegetation cover and ecosystem function (Tilman and Lehman 2001), also in environments where negative plant-soil feedbacks operate. Other studies on negative plant-soil feedback could likely improve the understanding of spatio-temporal dynamics of clonal plants in herbaceous plant communities (Van der Maarel and Sykes 1993).

\section{Acknowledgements}

The authors thank Prof F. Zucconi for stimulating discussions. The research of M.R is supported by a grant of the Netherlands Organization of Scientific Research (NWO-ALW).

\section{References}

Armstrong J. and Armstrong W. 2001. An overview of the effects of phytotoxins on Phragmites australis in relation to die-back. Aquat. Bot. 69: 251-268.

Augspurger C.K. and Kelly C.K. 1984. Pathogens mortality of tropical tree seedlings: experimental studies of the effects of dispersal distance, seedling density, and light conditions. Oecologia 61: 211-217.

Benjamin N.F., Caitlin M.C. and Bertness D. 2004. Community level engineering effects of Triglochin maritima (seaside arrowgrass) in a salt marsh in northern New England, USA. J. Ecol. 92: 589-597.

Bertness D. and Hacker D. 1994. Physical stress and positive associations among marsh plants. Am. Nat. 144: 363-372.

Bever D.J. 1994. Feedback between plants and their soil communities in an old field community. Ecology 75: 1965-1977.

Bever D.J., Westover M. and Antonavics J. 1997. Incorporating the soil community into plant population dynamics: the utility of the feedback approach. J. Ecol. 85: 561-573.

Bever D.J. 2003. Soil community feedback and the coexistence of competitors: conceptual frameworks and empirical tests. New Phytol. 157: 465-473.

Blomqvist M.M., Olff H., Blaauw M.B., Bongers T. and Der Putten W.H. 2000. Interaction between above- and belowground biota: importance of small scale vegetation mosaic in a grassland ecosystem. Oikos 90: 582-598.

Bonanomi G. 2002. Il ruolo dell'eterogeneità ambientale, generata dai vegetali attraverso il ricambio aereo e radicale, sulla biodiversità a scala di comunità. $\mathrm{PhD}$ thesis, University of Ancona, Ancona.

Bonanomi G., Giannino F. and Mazzoleni S. 2005. Negative plant-soil feedback and species coexistence. Oikos (in press).

Bonanomi G. and Mazzoleni S. 2005. Soil history affects plant growth and competitive ability in herbaceous species. Commun. Ecol. 6(1): 23-28.
Bruno F., Stachowicz J. and Bertness M. 2003. Inclusion of facilitation into ecological theory. Trends Ecol. Evol. 18: 119-125.

Callaway R.M. 1995. Positive interaction among plants. Biol. Rev. 61: 306-349.

Callaway R.M., Brooker R., Choler P., Kikvidze Z., Lortie C., Michalet R., Paolini L., Pugnaire F., Newingham B., Aschehoug E., Armas C., Kikodze D. and Cook B. 2002. Positive interactions among alpine plants increase with stress. Nature 417: 844-848.

Callaway R.M. and Walker R. 1997. Competition and facilitation: a synthetic approach to interaction in plant communities. Ecology 78: 1958-1965.

Casal R., Castillo J.M., Luque C.J. and Figueroa M.E. 2001. Nucleation and facilitation in salt pans in Mediterranean salt marsches. J. Veget. Sci. 12: 761-770.

Castellanos E.M., Figueroa M.E. and Davy A.J. 1994. Nucleation and facilitation in saltmarch succession: interaction between Spartina maritima and Arthrocnemum perenne. J. Ecol. 82: 239-248.

Curtis J.T. and Cottam G. 1950. Antibiotic and autotoxic effects in praire sunflower. Bull. Torrey Bot. Club 77: 187-191.

Danin A. 1996. Plants of Desert Dunes. Springer-Verlag, New York.

De Rooij-van Der Goes P.C.E.M. 1995. The role of plantparasitic nematodes and soil-borne fungi in the decline of Ammophila arenaria L. Link. New Phytol. 129: 661-669.

Falinska K. 1995. Genet disintegration in Filipendula ulmaria: consequences for population dynamics and vegetation succession. J. Ecol. 83: 9-21.

Fitter A.H. 1986. Spatial and temporal patterns of root activity in a species-rich alluvional grassland. Oecologia (Berlin) 69: 594-599.

Grime J.P. 1998. Benefits of plant diversity to ecosystems: immediate, filter and founder effects. J. Ecol. 86: 902-910.

Hutchings M.J. and de Kroon H. 1994. Foraging in plants: the role of morphological plasticity in resource acquisition. Adv. Ecol. Res. 25: 159-238.

Klironomos J.N. 2002. Feedback with soil biota contributes to plant rarity and invasiveness in communities. Nature 417: $67-70$.

Little L.R. and Maun M.A. 1996. The "Ammophila problem" revisitated: a role for mycorrhizal fungi. J. Ecol. 84: 1-7.

Martin M., Snaydon R. and Drennan D. 1982. Lithium as a non-radioactive tracer for roots of intercropped species. Plant Soil 64: 203-208.

Olff H., Hoorens B., De Goede R.G.M., Der Putten W.H. and Gleichman J. 2000. Small-scale shifting mosaic of two dominant grassland species: the possible role of soil borne pathogens. Oecologia 125: 45-54.

Packer A. and Clay K. 2000. Soil pathogens and spatial patterns of seedling mortality in a temperate tree. Nature 404: 278-280.

Pedemasa M. 1981. Cyclic change and pattern in Arthrocnemum community in Sri Lanka. J. Ecol. 69: 565-574.

Singh H.P., Batish R.D. and Kohli K.R. 1999. Autotoxicity: concept, organisms and ecological significance. Crit. Rev. Plant Sci. 18: 757-772.

Streng R.D., Glitzenstein J.S. and Harcombe P.A. 1989. Woody seedling dynamics in a east Texas floodplain in forest. Ecol. Monogr. 59: 177-204. 
Tilman D. and Lehman C. 2001. Biodiversity, composition, and ecosystem processes: theory and concepts. In: Kinzing P., Pacala S. and Tilman D. (eds), The Functional Consequences of Biodiversity. Princeton University Press, Monographs in Population Biology Princeton, pp. 9-41.

Van der Maarel E. and Sykes M.T. 1993. Small-scale plant species turnover in a limestone grassland: the carousel model and some comments on the niche concept. J. Veget. Sci. 4: 179-188.

Van der Putten W.H. 2003. Plant defense belowground and spatiotemporal processes in natural vegetation. Ecology 84 : 2269-2280.

Van der Putten W.H., Van Dijk C. and Peters B.A.M. 1993 Plant-specific soil-borne diseases contribute to succession in foredune vegetation. Nature 362: 53-56.

Watt A.S. 1947. Pattern and process in the plant community. J. Ecol. 35: 1-22.
Wikberg S. and Mucina L. 2002. Spatial variation in vegetation and abiotic factors related to the occurrences of a ringforming sedge. J. Veget. Sci. 13: 677-684.

Wikberg S. and Svensson B.M. 2003. Ramet demography in a ring-forming clonal sedge. J. Ecol. 91: 847-854.

Wills C., Condit R., Foster R.B. and Hubbell S.P. 1997. Strong density-related and diversity-related effects help to maintain tree species diversity in a neotropical forest. Proc. Natl. Acad. Sci. USA 94: 1252-1257.

Zucconi F. 1994. Root dynamics in natural and agricultural plants and the making of domestication. In: Proceedings of the International workshop: Dynamics of Roots and Nitrogen in Cropping System of the Semi-arid Tropics. Patancheru, Andhra Pradesh, India, 21-25 November 1994, pp. 102-128. 